WIENER SLAVISTISCHES JAHRBUCH, Band 52/2006, 179-194

(C) 2007 by Österreichische Akademie der Wissenschaften, Wien

W I T O L D W O J O W I C Z

\title{
O „Szczęśliwości” Adama Naruszewicza. Przyczynek do idei wielkiego łańcucha bytu
}

„Szczęśliwość” Adama Naruszewicza ${ }^{1}$ ujawnia rozpad przedoświeceniowych struktur sakralności świata. Autor (III 21) „Szczęśliwości” parafrazuje „Die Glückseligkeit" Johanna Petera Uza ${ }^{2}$, co implikuje obecność szeregu wątków światopoglądowych, charakterystycznych dla epoki i podjętych w twórczości Uza. Poezja religijna Uza łączy wczesnonowożytną fizykoteologię, zmodyfikowaną przez teodyceę leibniziańską, z dającymi się z nią zintegrować motywami tradycji chrześcijańskiej, szczególnie biblijnej ${ }^{3}$.

${ }^{1}$ Opublikowana została w roku 1773 (ZPP, t. 7, cz. 2, s. 353-358; DN, t. 2 - tu jako XXI oda z III księgi „ód” na stronicach 87-90). Tekst przywołuję za edycją Dzieł Naruszewicza z 1778. Omówienie tekstu - zob. np. T. Kostkiewiczowa: Klasycyzm, sentymentalizm, rokoko, Warszawa 1975, s. 92-93; J. Platt: „Zabawy Przyjemne i Pożyteczne” 1770-1777. Zarys monografii pierwszego polskiego czasopisma literackiego, Gdańsk 1986, s. 276-280; B. Wolska: W świecie żywiołów, Boga i człowieka. Studia o poezji Adama Naruszewicza, Łódź 1995, s. 57 i n.

2 J. P. Uz: Sämtliche poetische Werke, hg. von A. Sauer, Stuttgart 1890, s. 111-113. Cytaty z utworów Uza podaję za edycją Augusta Sauera. Na źródło „Szczęśliwości” Naruszewicza nie wskazuje Julian Platt (Inspiracje literackie Naruszewicza i innych poetów ,Zabaw Przyjemnych i Pożytecznych", Pamiętnik Literacki 1970, z. 2, s. 242-280), wcześniej Z. Ciechanowska (Literatura niemiecka a polska w XVIII w., Pamiętnik Literacki 1936, z. 1, s. 20-35). Odnośnie do wątków ideowych „Die Glückseligkeit” (przewijających się w szeregu innych utworów, jak w „,Der standhafte Weise. An Herrn Hof-Rath C*” J. P. Uz, op. cit., s. 95-98) - zob. np. J. Stenzel: Uz ein Metaphysiker! w: Dichter und Bürger in der Provinz. Johann Peter Uz und die Aufklärung in Ansbach, hrsg. von E. Rohmer, Th. Verweyen, Tübingen 1998, s. 141 i n.; wcześniej E. Petzet: Johann Peter Uz, neu hrsg. von Th. Stettner, Ansbach 1930, s. 88-90. Tekst był przełożony na j. francuski w zbiorze Choix de poésies allemandes, par M. Huber, tome second, Paris 1766, s. 139-141. Zob. też charakterystykę zbioru Hubera, jego roli kulturowej - P. Hazard: Myśl europejska w XVIII wieku od Monteskiusza do Lessinga, przeł. H. Suwała, wstęp St. Pietraszko, Warszawa 1972, s. 393.

3 Zob. W. Sparn: Johann Peter Uz und das Ansbachische Gesangbuch von 1781 w: Dichter und Bürger in der Provinz. Johann Peter Uz und die Aufklärung in Ansbach, hrsg. von E. 
Kluczowy dla utworu problem szczęścia jest znamienny dla cywilizacji oświecenia ${ }^{4}$. Pojawia się on w niej pod wpływem „redukcji eschatologicznej” i mnożnika środowiska ${ }^{5}$. „Problem redukcji eschatologicznej” przewija się w rozprawach Reinharta Kosellecka. Nowoczesność rodzi się poprzez wyparcie wizji eschatologicznego kresu, oczekiwania czasu ostatecznego - kluczowej dla chrześcijańskiego rozumienia historyczności - i zastąpienie jego ideą postępu ${ }^{6}$. Nowożytne próby przedstawiania dziejów jako progresywnego i sensownego marszu ku wewnątrzświatowemu spełnieniu opierają się, według Karla Löwitha, na chrześcijańskim, teologicznym i historyczno-zbawczym schemacie jako sekularyzacja tego augustyńskiego dziedzictwa. Myśliciele XVIII wieku - co szczególnie podkreślał Carl L. Becker - pozostawali, nieświadomie, uzależnieni od doktryny religijnej. Dokonywali substytucji schematów pojęciowych myśli religijnej ${ }^{7}$. Zastąpienie szczęśliwości pozaświatowej dążeniem do szczęścia na ziemi jest tego przykładem ${ }^{8}$.

Specyfiką nowożytnego myślenia o świecie, dokonywanego jeszcze w kategoriach całościowego ładu' ${ }^{9}$, było łączenie tradycji - dla nowoczesnej świadomości wykluczających się - ezoteryki i teologii z materialistycznym przyrodoznawstwem. Po-

Rohmer, Th. Verweyen, Tübingen 1998, s. 168. Odnośnie do formacji duchowej Uza, związków teologii protestanckiej i oświecenia, „neologii“ zob. W. Sparn: Johann Peter Uz und das Ansbachische Gesangbuch von 1781, op. cit., s. 174-188; W. Sparn: Vernünftiges Christentum w: Wissenschaften im Zeitalter der Aufklärung, hg. von R. Vierhaus, Göttingen 1985, s. 18-57, wcześniej K. Aner: Die Theologie der Lessingzeit, Halle 1929.

${ }^{4}$ Zob. np. P. Hazard: Myśl europejska w XVIII wieku op. cit., s. 31-40. Hazard cytuje „Die Glückseligkeit” Johanna Petera Uza, przywołuje także jego poemat dydaktyczny „Versuch über die Kunst stets fröhlich zu sein" (ibidem, s. 31; zob. J. P. Uz: Sämtliche poetische Werke, hg. von A. Sauer, Stuttgart 1890, s. 111-113 oraz s. 215-278).

5 P. Chaunu: Cywilizacja wieku oświecenia, przeł. E. Bąkowska, Warszawa 1989, s. 233 i n.

6 R. Koselleck: Miniona przyszłość wczesnej nowożytności w: idem: Semantyka historyczna, wybór i opr. H. Orłowski, tłum. W. Kunicki, Poznań 2001, s. 51-74; idem: „Przestrzeń doświadczenia” i „horyzont oczekiwań” - dwie kategorie historyczne w: idem: Semantyka historyczna, op. cit., tu s. 371-388; idem: „Nowożytność”. O semantyce nowoczesnych pojeć ruchu, w: idem: Semantyka historyczna, op. cit., 321-322; w odniesieniu do idei postępu - zob. E. Cassirer: Die Philosophie der Aufklärung, Tübingen 1932, s. 147; K. Löwith: Historia powszechna i dzieje zbawienia. Teologiczne przesłanki filozofii dziejów, przeł. J. Marzęcki, Kęty 2002, s. 60-99. K. Löwith, op. cit., tu s. 154. Por. P. Rossi: Zatonięcie bez świadka. Idea postępu, przeł. A. Dudzińska-Facca, Warszawa 1998, s. 43-97, 99-127; Z. Krasnodebski: Upadek idei posteppu, Warszawa 1991. W odniesieniu do polskiego oświecenia zob. J. Platt „Zabawy Przyjemne i Pożyteczne”, op. cit., s. 174241.

${ }^{7}$ Idea pozostaje kluczowa dla rozumienia myśli oświecenia C. L. Becker: Państwo Boże osiemnastowiecznych filozofów, przeł. J. Ruszkowski, Poznań 1995, zob. też P. Chaunu, op. cit., s. 235.

8 Zob. też K. Löwith, op. cit. Odnośnie do „mnożnika środowiska” - zob. P. Chaunu, op. cit., np. s. 74 i n. oraz s. 175 i n.

9 Zasada pełni stworzenia czy jego ciągłości należy do typu idei elementarnych - zob. A. O. Lovejoy: Wielki łańcuch bytu. Studium z dziejów idei, przeł. A. Przybysławski, Warszawa 1999. Zob. też J. Cabaj: Arthura O. Lovejoya filozofia i koncepcja historii idei, Lublin 1989, zwłaszcza s. 79-103 (tu s. 83) wcześniej D. J. Wilson: Arthur O. Lovejoy and the Quest for Intelligibility, Chapell Hill 1980. 
znanie filozoficzno-przyrodnicze wiązane było z doświadczeniem egzystencjalnym i estetycznym, stawało się wykładem moralności ${ }^{10}$.

\section{The Great Chain of Being}

Arthur Lovejoy wskazywał, że w stuleciu XVIII i XIX dochodzi do załamania dziedzictwa trwającego bez mała dwa tysiąclecia myśli filozoficznej, budującego przy wielości modeli i interpretacji - ideę ,,wielkiego łańcucha bytu”, rozumienia wszechświata w kategoriach całości, pełni i ciąłości ${ }^{11}$. „Myślenie całościowe” ma charakter paradygmatu, pojęcie ,całości” pozostaje kluczową dyrektywą w rozumieniu świata:

(...) sollten wir das grosse Ganze kennen,

Dies Ganze, das kein Auge mißt

So würden wir nicht Fehler nennen,

Was regelmäßig ist

(J. P. Uz: Auf den Tod des Freiherrn von Cronegk, w. 85-88)

Ich Sterblicher will nicht den stolzen Nacken beugen

Vor einer höhern Macht

Die von umwölkten Thron, aus heiligen Finsternissen,

Das große Ganze still regiert,

Und uns nach einem Plan, von dem wir wenig wissen,

Durchs kurze Leben führt?

(J. P. Uz: Das Schicksal, w. 27-32)

Model nacechowany niezmiennością całości, realizującej ideę ciągłości, ustępuje miejsca modelowi procesualności, czasowości i różnorodności, charakterystycznemu dla romantyzmu i omawianych przez niego prac Schlegla, Schleiermachera czy Schellinga $^{12}$. Tradycja myśli europejskiej wynika dla A. Lovejoya z całościowej wizji świata platonizmu i arystotelizmu, zintegrowanej w religii chrześcijańskiej, dostarczającej paradygmatu dla teologicznego rozumienia świata. Powstająca wiedza zaczęła burzyć porządek wprowadzony w uniwersum za sprawą wiary. Pod wpływem dociekań naukowych ujawnione zostały niespójności i sprzeczności w modelu kreacyjnym czy emanacyjnym ${ }^{13}$. Nauka europejska dopiero w wieku XX podległa skrajnej racjonalizacji, co nie oznaczało uwolnienia jej od irracjonalizmu czy schematów teologicznych. Wykorzystanie przez myślicieli XVIII wieku doktryn ezoterycznych jest efektem deficytu poznawczego i świadectwem stanu ówczesnej nauki ${ }^{14}$. Proces upadku wiedzy ezoterycznej rozpoczyna się dopiero w latach osiemdziesiątych XVIII wieku pod wpływem rozwoju przyrodoznawstwa i tendencji ra-

${ }^{10}$ L. Miodoński: Całość jako paradygmat rozumienia świata w myśli niemieckiej przełomu romantycznego. Analiza wybranych problemów, Wrocław 2001.

11 A. O. Lovejoy, op.cit. Zob. też W. Szturc: Oświecenie-Romantyzm. Z dziejów idei Natury i Wielkiej Całości w: Między oświeceniem i romantyzmem. Kultura Polska około 1800, red. Z. Lichański, B. Schultze, H. Rothe, Warszawa 1997, s. 193-210.

12 A. O. Lovejoy, op. cit. s. 337 i n.

13 A. O. Lovejoy, op. cit. ibidem. Zob. też np. P. Chaunu, op. cit., s. 171-252.

14 L. Miodoński, op. cit., s. 71-72. 
cjonalistyczno-oświeceniowych ${ }^{15}$. Bez uwzględnienia tych faktów zainteresowania myślowe ówczesnych elit pozostaną pełne niekonsekwencji i niezrozumiałe. Obraz myśli epoki, jaki się odsłania, łączy nieustannie przyrodoznawstwo, wiedzę empiryczną z mistyką, ezoterykę z racjonalizmem ${ }^{16}$.

\section{ORDNUNG}

Naruszewicz pomija pierwszą strofę „Die Glückseligkeit” zawierająca posłannictwo Prawdy udzielone autorowi i inwokację do niej. Obraz ewokujący w swym stylistycznym ukształtowaniu - jak często w imitacyjnej praktyce poetyckiej Naruszewicza ${ }^{17}$ - „Hymn” ${ }^{\text {18 }}$ Kochanowskiego otwiera „Szczęśliwość”:

Patrz, jak na niebie w niezgasłym orszaku

Każda pilnuje zorza swego znaku,

A niezmieszanym od wieku szeregiem

Hetmańskim słońca bieg swój mierzy biegiem ${ }^{19}$.

U Uza:

Es flammt ein Welten-Heer in angewiesnen Gränzen:

Es ist im lichten Raum, wo in bestimmter Bahn

Die ungezählten Sonnen glänzen,

Der Ordnung alles unterthan.

${ }^{15}$ L. Miodoński, op. cit., s. 110. Zob. też E. Cassirer: Die Philosophie der Aufklärung, Tübingen 1932, s. 36-47.

16 L. Miodoński, op. cit., s. 19-20.

17 Por. np. analizy ,liryków opisowych o charakterze sielskim” Juliana Platta (idem: Sielanki i poezje sielskie Adama Naruszewicza, Wrocław 1967, s. 160-172), uwagi M. Cieńskiego (idem: Kompozycja Sielanek Adama Naruszewicza, w: Od Kochanowskiego do Mickiewicza. Szkice o polskim cyklu poetyckim, red. B. Kuczera-Chachulska, Warszawa 2004, s. 92-93).

18 Podstawowym źródłem modlitwy dziękczynnej Kochanowskiego jest traktat De natura deorum Cicerona (Cicero: De natura deorum, ed. W. Ax, Stuttgart 1968). Stoik Balbus dowodził istnienia bogów $\mathrm{z}$ harmonii świata - był panteista, wielbiąc naturę, ubóstwiał ją - zob. W. Weintraub: O poezji religijnej Jana Kochanowskiego w idem: Nowe studia o Janie Kochanowskim, Kraków 1991, s. 73-74 odnośnie traktatu De natura deorum zob. A. Bleich-Schade: Studien zu Ciceros Religionsphilosophie, Bielefeld 1996, s. 35-108, w szczególności mowy Balbusa - ibidem, s. 73-82; K. Löwith, op. cit., s. 154 i n. Oddziaływanie Kochanowskiego w literaturze Oświecenia - zob. W. Walecki: Jan Kochanowski w literaturze i kulturze polskiej doby oświecenia, Wrocław 1979, Z. Libera: Dziedzictwo poezji Jana Kochanowskiego w literaturze późniejszej w: Jan Kochanowski i kultura odrodzenia, red. Z. Libera i M. Żurowski, Warszawa 1985, s. 184-206, zwłaszcza s. 189 i n. oraz T. Chachulski: Opóźnione pokolenie. Studia o recepcji „głębokiej” Jana Kochanowskiego w poezji polskiej XVIII wieku, Warszawa 2006.

19 Realia parafrazy ody Uza pozostają sarmackie - pojawia się określenie ,hetmański szereg”. Centralnym przedmiotem rozważań Cz. Zgorzelskiego pozostawała świadomość poetycka Naruszewicza zawarta w praktyce językowej: tworzenia dykcji klasycystycznej na bazie języka sarmackiego (idem: Od Oświecenia ku Romantyzmowi i współczesności, Kraków 1978, s. 51-83 (rozdz. Naruszewicz - poeta)). 
Zwraca uwagę zmian liczby „słońc” w parafrazie Naruszewicza, która czyni ją bardziej „ortodoksyjną”, nie ewokuje myśli o wielości światów. Skala ciągłego bytu została tym samym u Naruszewicza zredukowana. Przykładowo, w spekulacjach Immanuela Kanta z „Allgemeine Naturgeschichte und Theorie des Himmels" ${ }^{20}$ uwidaczniała się w jaskrawy sposób zasada ciągłości bytu - w racjonalnie zbudowanym wszechświecie większość planet posiadać będzie rozumnych mieszkańców. Skala bytu rozciąga się w istocie poza człowieka - życie i myślenie nie będzie ograniczać się do jednej planety ${ }^{21}$.

Doskonałość stworzenia ukazana w eksordium, zgoda i harmonia jest tu wynikiem równowagi, niezmienny porządek wyraża także niepodleganie rzeczywistości eterycznej procesowi zmiany i starzenia ${ }^{22}$. Harmonia w rzeczywistości nadksiężycowej owocuje ładem w rzeczywistości sublunarnej:

Wszystko się stało i trwa pewnym rządem:

Ląd się z wodami, woda wiąże z lądem.

Ona [sc. dusza] wiatrami rządząc na przemiany,

Morskie podnosi i muszcze bałwany.

Zmienność sublunarna wyraża w istocie ład. Inną myśl podejmą kolejne wersy:

Jej [sc. duszy] rozrządzeniem jedna łączy sfora,

Od człeka aż do lichego komora.

(w. 11-12)

Wyobrażenie ładu funkcjonuje jako argument. Poświadcza także wagę dawnego arystotelesowsko-ptolemejskiego modelu świata, doskonale sugestywnego, atrakcyjnego dla poetów ${ }^{23}$. Tekst Naruszewicza podejmuje ten obraz, wyraża idee panpsy-

${ }^{20}$ Immanuel Kant: Allgemeine Naturgeschichte und Theorie des Himmels oder Versuch von der Verfassung und dem mechanischen Ursprunge des ganzen Weltgebäudes, nach Newtonischen Grundsätzen, Königsberg und Leipzig 1755, s. 133 (cyt. podaje A. Lovejoy, op. cit., s. 255).

21 A. Lovejoy, op. cit., s. 221-227. Problemem zajmuje się Kant, zwłaszcza w części 3. swej Theorie des Himmels pt. Vergleichung zwischen den Einwohnern der Gestirne.

22 Zob. B. Wolska, op. cit., s. 10 i n. Kanonicznym tekstem jest tu traktat Arystotelesa „O świecie" w: Arystoteles: Dzieła wszystkie, przeł., wstęp K. Leśniak i inni, t. 2, Warszawa 1990, s. 569-600. Zob. też N. Wildiers: Obraz świata a teologia. Od średniowiecza do dzisiaj, Warszawa 1985, s. 27 i n.; w odniesieniu do rozumienia natury i praktyk poznawczych zob. np. klasyczne studium Ernsta Cassirera (op. cit, s. 48-122). Należy podkreślić za K. Löwithem nieprzywiedlność czy sprzeczność pomiędzy grecką kontemplacją widzialnego świata (theoria) a wiarą chrześcijańską (pistis) - „ślepą“ ufnością w to, co niewidzialne - K. Löwith, op. cit., s. 154-160.

23 B. Wolska podkreśla (op. cit., S. 24-26) za C. S. Lewisem, iż model ten funkcjonuje - czy zaczyna funkcjonować wraz z odejściem starożytnej kosmologii - na zasadzie licentia poetica i dla poetów XVIII wieku nie wyklucza wiedzy o nowej kosmologii. Nie rozstawano się z pojęciami tak charakterystycznymi dla kultury. Stąd Model staje się tworem literackiej dykcji z swym podziałem na sferę podksiężycową i nadksiężycową z Bogiem jako poruszycielem (por. np. Naruszewicza (II 16) „Hymn do Boga” (DN, t. 1, s. 183185), ale także i (I 2), „Hymn do Słońca” (DN, t. 1, s. 8-12, w. 57-72) - B. Wolska, op. 
chizmu $^{24}$. Zwraca uwagę idea kontinuum rozciągającego się poprzez wszystkie formy natury. Nie ma w istocie szczelin czy stopni pomiędzy rozmaitymi formami życia, różnorodnymi przejawami organicznej i nieorganicznej natury. W istocie występuje tu ciagłość pomiędzy najbardziej elementarnymi procesami życiowymi aż po procesy poznawcze, właściwe człowiekowi. Więzy „,rządu” nadają światu organiczną jedność i obdarzają go świadomością. Rozumna wewnątrzświatowa świadomość wypiera Boga z obrazu wszechświata, usuwając także źródło niepewności i nieprzewidywalności, kategoryzowanej w figurze Fortuny. Bóg „Szczęśliwości” staje się w stworzeniu, dzieje się tak kosztem zniesienia dualizmu Bóg - fortuna, charakterystycznego dla całej kultury dawnej ${ }^{25}$. Myśli w przywołanych niżej wersach nie można wiązać z przenikającym świat, rządzącym go rozumem Boga tradycji judeochrześcijańskich. Boga nie postrzega się zgodnie z fundamentalnym rysem religii monoteizmu biblijnego jako istoty poza kosmosem, który jest jedynie jego kreacja. Ujawnia się siła wyobrażeń wiązanych z całościową koncepcją Bytu. Idea panpsychizmu pozwala na eliminację przypadkowości ze względu na bezwyjątkowość i ogólność władztwa ,jednej duszy"26:

Jeśli się ten świat i żyje, i rusza,

Tysiącem istot jedna władnie dusza.

Rozpościera się ona w każdym bycie przypisanym rzeczywistości sublunarnej i wypiera z niej władztwo Fortuny, odpowiedzialnej za niestałość tej części stworzenia.

Granica pomiędzy elementem nieożywionym, a tym, co żywe ulega w poetyckiej dykcji Naruszewicza zatarciu. Widzieć w tym można nie tyle naiwny panteizm, ile aspekt trwałej recepcji neoplatonizmu chrześcijańskiego - z jej doktryną wszecho-

cit., s. 65-68, 191-194, szerzej: B. Wolska: O „Hymnie do Słońca” w: Czytanie Naruszewicza. Interpretacje, pod red. T. Chachulskiego, Wrocław 2000, s. 11-27; R. Rippel: O „Hymnie do Słońca”, ibidem, s. 29-36. Podobnie dzieje się w twórczości Uza, by wspomnieć „Gott, der Weltschöpfer” (Zu Gott, zu Gott flieg auf, hoch über alle Sphären! / Jauchz ihm, weitschallender Gesang, / Dem Ewigen [...] Von ihrer hohen Bahn, in jener lichten Ferne, / Jauchzt ihm die Sonne freudig zu: / Du machtest mich! du Gott! Und ringsumher die Sterne, / Das Heer des Himmels; machtest du! / Sein Lob, ihr schimmerreichen Schaaren, / Tönt auf der dunkeln Erde nach, / Von Wesen, die nicht waren, / Und wurden (...) (w. 1-3, 9-16).

24 E. Petzet zwraca uwagę, że o ile stale wykorzystywany przez Uza „Essay on Man” Aleksandra Pope'a - w „Teodycei” czy w „Versuch über die Kunst stets fröhlich zu sein” podejmuje wątki panteistyczne, o tyle Uz stara się wyrazić światopogląd bliskiego mu chrześcijaństwa (E. Petzet: Johann Peter Uz, neu hrsg. von Th. Stettner, Ansbach 1930, s. 97 i n.).

25 J. Delumeau: Grzech i strach. Poczucie winy w kulturze Zachodu XIII-XVIII w., przeł. A. Szymański, Warszawa 1994, s. 209-268 (rozdz. I 5: Słaby człowiek).

${ }^{26}$ W wierszu Uza: Ihr Band verknüpfet alle Wesen, / Vom Staube bis zu Cherubin. (w. 1112). W miejsce „więzi” (Band der Ordnung) kładzie Naruszewicz „duszę”, wzmacniając aspekt panteistyczny tekstu. 
becności zasady we wszystkich rzeczach, a zarazem radykalnej odrębności Boga w stosunku do stworzeń ${ }^{27}$.

\section{PARADYGMATY}

Paradygmat mechanicystycznego wyjaśniania przyrody, właściwy stuleciu XVII i pierwszej połowie XVIII wieku, odnoszony do świata istot żywych, ulega w drugiej połowie XVIII wieku - nie wolno zapominać o źródle utworu Naruszewicza, „Die Glückseligkeit” Uza pochodzi z początku lat pięćdziesiątych XVIII wieku ${ }^{28}$ charakterystycznej przemianie. Model opisu powstały w związku z istotami żywymi przenosi się na całość rzeczywistości - tak naturalnej, jak i duchowej ${ }^{29}$. Koncepcja organicznej całości, jedności świata-organizmu w wielości form życia wyraża w istocie myśli o charakterze panteistycznym - idei jedności nieskończonego i skończonego. Pamiętać trzeba także, że już u schyłku XVIII wieku rozgorzał wielki i gwałtowny spór o panteizm, związany z wielością monistycznych ujęć świata, mających bogate tradycje: mistyka (korzystająca z tradycji neoplatonizmu), protestancki pietyzm, hermetyzm i wiedza ezoteryczna (astrologia, alchemia, kabała), przyrodoznawstwo (prócz doktryn racjonalistycznych, i materialistycznych należą tu także ezoteryczne i teologiczne ujęcia świata), dziedzictwo spinozjańskiego panteizmu ${ }^{30}$.

Oda (III 26) „O powinności człowieka w towarzystwie ludzkim”, będąca parafrazą utworu Antoine L. Thomasa „Les Devoirs de la société” (DN, t. 2, s. 106-111) ukazuje celowość ładu, wyrażającego ,pracę” elementów, prowadzi do utylitarystycznych wniosków o powinności życia pracowitego człowieka, właściwego członka nasyconego ładem społeczności ${ }^{31}$. Oda eksponuje, podejmując myślenie - w kontekście powinności człowieka - o Wszechświecie w kategoriach całościowego ładu, wątki mechanicystyczne, w przeciwieństwie do organicystycznych, charakterystycznych dla naruszewiczowskiej „Szczęśliwości”32.

Patrz wokoło na dziwne rąk przedwiecznych czyny, Jak się kragły świat dźwiga zgodnemi sprężyny.

27 Dla platonizmu chrześcijańskiego Bóg będąc transcendentny ontycznie, także poznawczo, jest jednocześnie immanentny światu, obejmując całość świata (zob. np. W. Beierwaltes: Platonizm w chrześcijaństwie, przeł. P. Domański, Kęty 2003).

${ }^{28}$ Zob. np. J. Stenzel: Uz ein Metaphysiker! w: Dichter und Bürger in der Provinz, op. cit., s. 145.

29 R. Panasiuk: Dialektyka Hegla i paradygmat witalistyczny w: idem: Przyroda. Człowiek. Polityka. Z dziejów filozofii niemieckiej XVIII/XIX wieku, Warszawa 2002, s. 96-97 z odwołaniem do pracy J. Schlanger: Les métamorphoses de l'organisme, Paris 1971.

${ }^{30}$ L. Miodoński, op. cit., s. 53-144, tu s. 116. Należy podkreślić wagę doktryn ezoterycznych w całokształcie myśli XVIII wieku - zob. np. studium wstępne M. NeugebauerWölkl pt. Esoterik im 18. Jahrhundert - Aufklärung und Esoterik. Eine Einleitung w: Aufklärung und Esoterik, hrsg. von M. Neugebauer-Wölkl, Hamburg 1999, s. 1-37.

31 J. Platt: „Zabawy Przyjemne i Pożyteczne”, op. cit., s. 275-276; Por. B. Wolska, op. cit., s. 52, 59 i n., wcześniej T. Kostkiewiczowa: Klasycyzm, sentymentalizm, rokoko, op. cit., s. 90-93.

32 Por. B. Wolska, op. cit., s. 62. 
Nic tam próżno nie stoi: wszystko dzielnym ruchem

Toczy się, jakby jednym ujęte łańcuchem.

Wiatr powietrze, powietrzne wodę czyszczą wiewy,

Woda rodzajnym sokiem ziemne tuczy krzewy,

Ogień tyle gwiazd żywi niedościgłych okiem,

I tym, który ożywia, sam żyje obrokiem.

Ty sam ozdobny darem wiecznej duszy rzadkiem,

Mniemasz, żeś na ten okrąg wtrącony przypadkiem,

I jakbyś chciał natury stargać węzły wieczne,

Pędzisz Bogu i ludziom dni nieużyteczne.

(III 26, O powinności człowieka w towarzystwie ludzkim, w. 9-18)

Krytyka tendencji mechanicystycznych w przyrodoznawstwie XVIII wieku przyczyni się do powstania tzw. romantycznej filozofii przyrody - kluczowym dla niej wyobrażeniem będzie ujmowanie całości rzeczywistości w kategoriach żywego organizmu kosmicznego, pobudzanego przez energię o charakterze organicznym. Nieredukowalność życia do procesów mechanicznych w kolejnym etapie poprowadzi do ujawnienia fundamentalnej odrębności istot żyjących od pozostałej części przyrody i próby wytłumaczenia różnicy, dzielącej istoty żywe od tworów nieorganicznych $^{33}$.

W myśli XVIII wieku tworzonej w ramach paradygmatu całości daje się wyznaczyć kilka modeli widzenia całościowego świata ${ }^{34}$. Całościowo-organiczne wątki podejmuje Naruszewicz w „Szczęśliwości”, wątki całościowo mechanistyczne obecne są w odzie (III 26) „O powinności człowieka w towarzystwie ludzkim”.

\section{SZCZĘŚCIE}

Panowanie powszechnego porządku wymaga, aby wszystkie stworzenia były szczęśliwe:

Rząd a powszechne dobro, moim zatem

Prawdziwym dobrem. Jeśli mącę światem

I z przepisanej sam kluby wypadam,

Próżno się chełpię, że szczę́scie posiadam.

Podporządkowanie się „rządowi” zapewnia uczestnictwo w „powszechnym szczęściu”. Identyfikacji ze zbiorowością nie sposób odrzucić, nie wykluczywszy się z uczestnictwa w „dobru”35.

${ }^{33}$ Zob. np. R. Panasiuk: Newton i źdźbła trawy w: R. Panasiuk, op.cit., s. 24-38.

34 L. Miodoński, op. cit., s. 23, zob. też ibidem, s. 156-158.

35 Ten aspekt wyrażony w wersie 13 i 14 ,Szczęśliwości” jest silniejszy w tekście Uza: Ich werde glücklich seyn, wenn ich durch keine That / Dies allgemeine Wohl verletze, / Für welches ich die Welt betrat: (w. 14-16). „Rząd” (w. 13) Naruszewicza jest synonimem „Harmonie” (w. 19) u Uza. 
Dążenie do prywatnego dobra popadać musi z konieczności w konflikt z dobrem innych ludzi, a zatem niezgodne jest z prawem moralnym, w konsekwencji niezgodne jest $\mathrm{z}$ naturą ${ }^{36}$. Dostrzec można $\mathrm{w}$ tym przedstawieniu teologię grzechu pierworodnego, modelowego wyobrażenia dla potępianego egoizmu ${ }^{37}$. Być może jednak to, co Naruszewicz w swym poetyckim dyskursie pragnie wypowiedzieć, to myśl o niezależności dążenia do szczęścia powszechnego od dążenia do indywidualnego szczęścia, wyrażonego we własnej przyjemności i - o czym się tu nie wspomina - w unikaniu cierpienia. W gruncie rzeczy jednak nie ma w przywołanym fragmencie „Szczęśliwości” miejsca na osobowość ludzkiego podmiotu i indywidualizm, stąd waga panpsychizmu, założonego w naturze przez dyskurs Naruszewicza. Status człowieka określony zostaje poprzez relację do całości bytu, w tym także bytu społecznego. W ten sposób kresem uzasadnienia moralności - sedno projektu oświeceniowego i nieprzezwyciężonego w jego ramach problemu - nie staje się w ostatecznej instancji wybór, dokonany przez indywiduum, który nie opiera się na żadnych wcześniejszych kryteriach, i który nie może być już dalej uzasadniany. Ten kluczowy problem oświeceniowej etyki - wybór będący kresem uzasadniania - staje się niewyrażalny. Ale i niewyrażalna pozostaje - przy jednym z możliwych odczytań tych wersów - podmiotowość czynów moralnych, zdolność umieszczana trwale w osobowości, nie w uniwersum panteistycznego ładu.

Rozumność natury to także jej świadomość:

Na wszystkie członki jedna się rozlewa

Boleść i zdrowie: gdy jeden omdlewa,

W powszechnym związku, długo-li, krótko-li,

Drugi też wyznać musi, że go boli. ${ }^{38}$

(w. 17-20)

W miejsce szczęścia i dążenia do przyjemności akcentuje Naruszewicz cierpienie i niezdolność do jego uniknięcia. W tym ostatnim aspekcie skłonny byłbym dopatrywać się myśli o skażeniu natury ludzkiej, wyrażonej w panteistycznym kostiumie - co raz jeszcze uwydatnia tak charakterystyczne z perspektyw współczesnej niekonsekwencje myślowe i zapośredniczony w tradycjach chrześcijańskich eklektyzm Naruszewicza, poszukującego wzorców kulturowych i literackich dla wyrażenia ostatecznie idei wanitatywnych. Problem szczęścia staje się jeszcze bardziej abstrakcyjny - skontrastowany z nieszczęściem, którego realia wypowiadane zostają

${ }^{36}$ Por. odę (III 26) „O powinności człowieka w towarzystwie ludzkim”, zob. też B. Wolska, W świecie żywiołów, op. cit., s. 52.

37 Korzystam ponownie z myśli Carla L. Beckera. Myśliciele oświecenia pozostawali w wysokim stopniu uzależnieni - nie będąc tego świadomi - od ,przedzałożeń myśli średniowiecznego chrześcijaństwa" (C. L. Becker, op. cit., tu s. 28-29).

38 Wersy od 17 do 24 tekstu Naruszewicza są amplifikacją w stosunku do „Die Glückseligkeit" Uza w edycji Augusta Sauera. Wątki pokrewne, podjęte przez Naruszewicza, mogły być przejęte za np. „Der standhafte Weise” Uza (J. P. Uz: Sämtliche poetische Werke, op. cit., s. 95-98). 
przy pomocy dziedzictwa mitologicznego chrystianizmu. Nieszczęście, ból, konceptualizowane w myśli teologicznej przy pomocy konsekwencji ,grzechu pierworodnego", są nieuniknioną podstawą rzeczywistości.

Naruszewicz konstatuje ciagłość między jednostką i społeczeństwem - teraz podkreśla ciągłość między człowiekiem a naturą. Zbiorowość nie jest wyodrębniana $\mathrm{z}$ całości bytu, podobnie jednostka. Uczestnictwo w uniwersalnym bycie oznacza także przyjęcie cierpienia, które ma właściwe sobie miejsce. Całość uniwersum przenika święta siła - tak w zbiorowości, jak w całości bytu. Poznanie filozoficznoprzyrodnicze powiązane zostaje $\mathrm{z}$ doświadczeniem egzystencjalnym i estetycznym. Zależności tych nie ma między heterogenicznymi w świadomości współczesnej dziedzinami - jak poznanie przyrody i refleksja egzystencjalna czy estetyczna.

Człowiek realizuje się poprzez wypełnianie powinności względem grupy. W istocie życie istot ludzkich winno stosować się do kilku elementarnych przykazań:

Równym spojeni na świecie ogniwem,

Żyjemy ludziom: kto bliźniemu krzywem,

Będzie i sobie; a taż sama wada,

Co innym szkodzi, i na niego spada.

(w. 21-24) $)^{39}$

Nie ma tu odpowiedzi na pytanie skąd „zło” Naruszewicz w swej poetyckiej antropologii nie odpowie na pytanie, czy „miłość własna” należy do natury i dlaczego miałaby skazić „naturalne” powinności człowieka:

Więc jeśli serce powolne nie skaża

Swych powinności, jeśli nie obraża

Spólnej osnowy, interes mych chuci,

Gnuśny niewolnik, gdy mi nie wyrzuci

Żaden, iż w sobie samym rozkochany,

Ludzkich towarzystw wszystkie psuję stany;

Gdy czyniąc sobie, drugim dobrze czynię:

Wtenczas się nazwę szczę́liwym jedynie.

(w. 25-32)

Charakterystyczne dla dykcji Naruszewicza, barokizujące w swej estetyce obra$\mathrm{zy}^{40}$, zawarte w kolejnych strofach, wyczerpują swe znaczenie za sprawą funkcji ukazania nieładu jako czegoś nieestetycznego, w przeciwieństwie do ładu mającego charakter estetyczny:

Mętnych rozkoszy źródło swym wypadem

I najkraśniejszy kwiat zaraża jadem ${ }^{41}$;

39 Strofa - podobnie jak poprzednia (w. 17-20) - jest amplifikacją tekstu Johanna Petera Uza. Amplifikacji nie zawiera również przekład zawarty w edycji Hubera (op. cit.).

40 Zob. np. uwagi W. Borowego (O poezji polskiej w wieku XVIII, Warszawa 1978, s. 8299), J. Platta (Inspiracje literackie Naruszewicza op. cit., s. 279-280).

${ }^{41}$ U Uza jedynie: „Haucht ekle Bitterheit selbst unter Bluhmen aus” (w. 22). 
Na koło złotych dachów smutek lata,

A bojaźń i puch łabędzi ugniata.

[...] chciwa na krew i przemożne złoto,

Slepym podkopem czyha na mnie zdrada,

Zazdrość mię szarpie, a gmin płocho gada.

(w. 33-36, 42-44)

Poznanie filozoficzno-przyrodnicze powiązane wcześniej z doświadczeniem egzystencjalnym wyrażone zostaje teraz w kategoriach estetycznych. Tak jak etyka powiązana jest z fizyką, tak piękno współistnieje z przyroda, cnota z prawdą i pięknem - w zakończeniu utworu. Naruszewicz pozostaje jednak bezradny w obliczu pytania, jak stawić czoła podszeptom natury ludzkiej, takim choćby jak przekupstwo:

Gardzę szafunkiem ludokupnej dłoni,

Co mi chcąc cnotę wydrzeć, workiem dzwoni.

Perspektywa natychmiastowych zaspokojeń, korzyści majątkowych, wydaje się pociaggająca, choć odrzucana. Nie rozważa on, arystotelesowskiego w istocie problemu, że szczęście, dobro może być zniweczone przez okoliczności natury zewnętrznej. Nie jest on arystotelikiem, wierząc uparcie, iż o ile sami nie jesteśmy współwinni, przekładając ,interes mych chuci”, nad cnotę, a zatem uczestnicząc w złu, nie ma przeszkód stojących na drodze do szczęścia. Nie mogą ich stanowić żadne okoliczności natury zewnętrznej w stosunku do człowieka ${ }^{42}$ :

Słodka wesołość w czystym tylko rada Sercu przebywa; tam gniazdo zakłada, Gdzie jej poczciwe wskazuje sumienie, Bądź carski pałac, bądź smutne więzienie.

Temu gdy ufam, niewiele dbam o to, Że chciwa na krew i przemożne złoto, Ślepym podkopem czyha na mnie zdrada, Zazdrość mię szarpie, a gmin płocho gada.

Bym miał do zgonu żywot pędzić lichy,

Nie chcę ja żebrzeć o litość u pychy;

Gardzę szafunkiem ludokupnej dłoni,

Co mi chcąc cnotę wydrzeć, workiem dzwoni.

Kontrast pomiędzy głupcem niewolonym pragnieniami, namiętnościami i żądzami, i samowystarczalnym i dlatego mądrym człowiekiem, służy pochwale tego ostatniego. Towarzyszy temu kojące przeświadczenie, wyrażone w poprzednich strofach, że uczestniczy się w jakiejś panpsychicznej naturze, odpowiedzialnej za dobro i jego udział w tym, co istnieje.

${ }^{42}$ A. MacIntyre: Dziedzictwo cnoty. Studium z teorii moralności, przeł. A. Chmielewski, Warszawa 1996, s. 318. Tego typu obiegowe wątki są częste w twórczości Naruszewicza, zob. np. (IV 12) „Do potwarców” (DN, t. 2, s. 151-154). 
Pociechę w „Szczęśliwości” buduje ideał mierności:

Wdzięczny pokoju, darze w ludziach rzadki! Idź ze mną, proszę, choć do kmieciej chatki, Kędy na łonie nieszkodnej rozkoszy

Niewinność snów mi słodkich nie wypłoszy.

Szczęście buduje ideał złotego środka. Horacjańska szczęśliwość realizuje się w marzeniu o wiejskim domku, wyraźna jest także w tradycjach sielankowych podjętych w przywoływanym już „Folwarku”. Podobne wątki oparte na stereotypach etyki stoickiej - do której częstokroć odwoływali się filozofowie oświecenia ${ }^{43}$ - odnaleźć można również w zakończeniu (III 26) „O powinności człowieka w towarzystwie ludzkim"44. Pisał Naruszewicz, parafrazując A. Thomasa:

Nie dbaj, że cię serc wdzięcznych pominą dowody,

Masz w Bogu, masz w twych cnotach hojniejsze nagrody.

Okazalszy stąd zaszczyt, czystej sławy próby:

Sama niewdzięczność większej przydaje ozdoby.

(w. 101-104)

W „Szczęśliwości” napisze:

Nie Epikurskiej gnuśny uczeń szkoły ${ }^{45}$,

Oddaje panom łzami zlane stoły,

Przestając na tym, co ubóstwem ścisłem,

A mądrym stawię na obrus przemysłem.

(w. 53-56)

${ }^{43}$ E. Tugendhat: Wykłady o etyce, przeł. J. Sidorek, Warszawa 2004, s. 229. Przedkładanie „kmieciej chatki” na „pałac” odnajdziemy, przykładowo, w „Dialogach” Seneki Młodszego (VII, Ad Gallionem. De vita beata, 25.1). Tego typu motywy wykorzystał Naruszewicz w wielu utworach, szczególnie przypisanych królowi Stanisławowi Augustowi - zob. np. (III 24) „Pociecha cnoty. W dzień imienin J. K. Mci” (DN, t. 2, s. 97-102); zob. też T. Kostkiewiczowa: Polski wiek świateł, op. cit., s. 112-139.

${ }_{44}$ Zob. J. Platt: Sielanki i poezje sielskie, op. cit., s. 82-83; B. Wolska, op. cit., s. 62-63.

45 Naruszewicz ,podmienił” tu występującego w „Die Glückseligkeit” Uza Arystypa (w. 21), przedstawiciela skrajnego hedonizmu, na Epikura, doskonale znanego, tradycyjnie potępianego za przypisywany mu hedonizm. Zob. np. Der Garten und die Moderne. Epikureische Moral und Politik vom Humanismus bis zur Aufklärung, Hrsg. G. Paganini, E. Tortarolo, Stuttgart 2004 tu - prócz studiów szczegółowych - rozprawa G. Gawlicka: Epikur bei den Deisten (s. 323-339) i W. Schröder: Naturphilosophische Spekulation im Dienste einer praktischen Zielsetzung. Neo-Epikureismus in der Aufklärung (s. 343-360). W strofie Naruszewicz jedynie parafrazuje Uza, przydając poetyckiej refleksji nieobecny w oryginale wymiar społeczny: Fehlt innre Ruhe nicht; was fehlet meinem Leben, / Als was entbehrlich ist und unentbehrlich scheint? / Soll ich bei jedem Unfall beben, / Und weinen, wann die Thorheit weint? (w. 37-40). Podstawą prafrazy nie jest też przekład tej strofy w edycji Hubera (op. cit., s. 140): Que, manque-t-il à ma vie, sinon ce superflu que tant de gens prennent pour un besoin? Ce n'est qu'à la débile enfance que les chagrins coutent des larmes. 
Przywołując obrazy, będące bardziej imitacją „Pieśni” Kochanowskiego, niż „Die Glückseligkeit” Uza ${ }^{46}$, po raz kolejny odwoła się Naruszewicz do etycznej wartości natury:

Ten był od wieku los mieszkańców świata,

Że się wesołość frasunkiem przeplata:

Raz kwiaty sypie, lecz czasem chcąc wiernie

Od szwanku odwieść, prowadzi na ciernie.

(w. 57-60)

W istocie, jesteśmy wychowankami Natury - karząc nas, zadając nam cierpienie, stara się naprowadzić na ideał cnoty, założony w niej samej. Proces daje się opisać jako teleologizację zła, znamienny jest dla nowożytności. Nieszczęście, cierpienie staje się środkiem do celu - osiagnięcia najlepszego szczęścia. Częściowe zło staje się niezbędne dla osiągnięcia dobra całości. Zło nie jest relatywizowane wraz z całością doczesności - tak działo się w nurtach chrześcijańskiej ortodoksji ${ }^{47}$. Zło staje się konieczną cechą otaczającej rzeczywistości, dzieje się tak dla dobra całości. Cechą optymistycznie nastawionych myślicieli XVIII wieku, dalekich od uznania nierealności zła, było wykazywanie jego konieczności w istniejącym świecie - na wskroś racjonalnym ${ }^{48}$. Naruszewicz powiela pewien sposób myślenia, znamienny dla szeregu myślicieli XVIII wieku: fakty, nawet nieprzyjemne, istnieją na mocy pewnych racji - jest nią w istocie nasze szczęście. Perspektywa ta nieobca była stoikom. Kosmos w tej percepcji jest żywym organizmem, obdarzonym swoista świadomością i wolą. Powszechny Rozum ma w istocie za cel dobro Całości - w tym sensie to zjawiska fizyczne jawią się jako nieprzyjemne, odpychające. Są one ubocznym lecz koniecznym następstwem pierwotnego bodźca Natury. Naszym zadaniem jest wyjście poza uprzedzenia i umieszczenie tych aspektów rzeczywistości na płaszczyźnie powszechnej Natury ${ }^{49}$. Względna nowość poetyckich wyobrażeń UzaNaruszewicza polega na rekombinacji pewnych sposobów rozumowania i wniosków, w istocie trwale wpisanych w kulturę śródziemnomorską.

Panpsychizm prowadzi ku uznaniu pewnego mechanizmu ziemskiej odpłaty, wypowiedzianego w kategoriach organicystycznych i przeniesionego w zaświaty w ko-

46 W „Die Glückseligkeit” Uza: Mit weiser Huld vertheilt das Schicksal Weh und Freuden, / Das bald auf Rosen uns durchs Leben wandern heißt, / Bald aber durchs bedornte Leiden / Des Lasters Armen uns entreißt. (w. 41-44). W Pieśni IX z „Ksiąg wtórych” Jana Kochanowskiego: Nic wiecznego na świecie: / Radość się z troską plecie, / A kiedy jedna weźmie moc nawiętszą, / Wtenczas masz ujźrzeć odmianę naprędszą. (II, 9, w. 13-16).

47 O. Marquard: Szczęście w nieszczęściu. O teorii szczęścia pośredniego między teodyceą a filozofią historii w: idem: Szczęście w nieszczęściu. Rozważania fillozoficzne, przeł. K. Krzemieniowa, Warszawa 2001, s. 10-14; por. C. L. Becker: Państwo Boże osiemnastowiecznych filozofów, op. cit., s. 52.

48 A. Lovejoy, op. cit., s. 243-266 (rozdz. Zasada pełności i osiemnastowieczny optymizm).

49 P. Hadot: Twierdza wewnętrzna. Wprowadzenie do „Rozmyślań” Marka Aureliusza, przeł. P. Domański, Kęty 2004, s. 135-186 (rozdz. VII Stoicyzm Rozmyślań. Dyscyplina pragnienia, czyli amor fati). 
lejnych strofach „Szczę́liwości”. Etyczny wymiar natury schodzi na plan dalszy w strofach ostatnich. Przywołuje się teistyczne wyobrażenie świata, nawiązujące przy tym do, ewokowanego także na płaszczyźnie leksykalnej, pawłowego „Hymnu do Miłości" ${ }^{50}$ :

Lecz kiedy ów czas przyjdzie, gdy przed oczy

Cała się rzeczy śmiertelnych zatoczy

Osnowa, którą przed ułomnym wzrokiem

Bóg niedostępnym zawinął obłokiem.

Naruszewicz zamyka utwór wprowadzając wątki chrześcijańskie. Ten aspekt uwydatnia synkretyzm Naruszewicza w podejmowaniu wątków kulturowych. Szczęście można osiągnąć, ale dopiero w zaświatach. W istocie, jak w tradycyjnej moralistyce chrześcijańskiej, na ziemi nie można ryzykować uczucia szczęścia. Ujęcia nie można nazwać arystotelesowskim: szczęścia nie można postrzegać za cel ludzkiego życia, które jest w wierszu rzutowane przez Naruszewicza w zaświaty. Szczęście w etyce arystotelesowskiej towarzyszy osiągniętej doskonałości, ale nie staje się ono kryterium kierowania naszym postępowaniem - jak u Naruszewicza. Szczęście towarzyszy wielu różnym, odmiennym czynnościom, zakończonym ich wypełnieniem, ale nie jest przyczyną, dla której należy podjąć daną czynnośćć. Cnoty w arystotelizmie nie uprawia się dla szczęścia - jak w „Szczęśliwości”. W niekoherentny sposób Naruszewicz - i swoisty dla kultury umysłowej XVIII wieku - łączy to, co nowe: poszukiwanie szczęścia z refleksją arystotelesowską i tradycyjną dydaktyką religijną. Ludzie dążą do szczęścia, najwyższe dobro polega na moralnej doskonałości jednostki, zwieńczonej szczęściem, na które zasłużyła. Dydaktyka religijna nastawiona na poczucie marności ludzkiej egzystencji, naznaczonej bezustannymi „troskami”, wchodzi tu w specyficzny alians z oświeceniem, poszukującym szczęścia już tu, na ziemi. Daje to zaskakujący efekt, zgodny z duchowością

${ }^{50}$ Por. fragment z 1 Listu do Koryntian św. Pawła (1 Kor. 13:9-10, 12). Istotny jest także kontekst izajaszowego przedstawienia czasów mesjańskich (Iz. 25:7-8). Nawiązania nie dostrzegł J. Platt (,Zabawy Przyjemne i Pożyteczne”, op. cit., s. 279). Do wyobrażenia z Listu Pawła nawiązał Naruszewicz również w odzie (I 11) Do Stanisława Augusta, króla polskiego, w. książęcia lit. etc. W dzień urodzenia 1771 (DN, t. 1, s. 47-51): Lecz to Bóg dla swych końców, odwiecznym wyrokiem, / Grubym chciał przed oczyma zasłonić obłokiem, / I troski roźlicznemi, jako kruszec złoty, / Doświadcza twej, o zacny Królu, dzielnej cnoty. (w. 53-56). W tekście Uza ostatnia strofa brzmi: Ein Blick in vorig Leid wird künftig uns entzücken, / Wenn unsrem Auge sich der Ordnung Plan entdeckt, / Der nun vor unsern kühnen Blicken / In heilig Dunkel versteckt. (w. 45-48).

51 A. MacIntyre, op. cit., s. 292-294. Tugendhat podkreślał, iż ważną cechą interpretacji MacIntyre'a koncepcji cnót Arystotelesa jest nie tyle definiowanie ich jako dyspozycji umożliwiających we wzajemnym obcowaniu jak najlepsze spełnianie człowieczeństwa jednostek, lecz jako spełnianie określonych czynności, nie ukierunkowanych instrumentalnie na zewnętrzne wobec nich dobro. Interpretacja przesuwa rolę cnót z pewnego sposobu współżycia w całości na ograniczone czynności wymagające kooperacji - przykładem MacIntyre'a są gry (E. Tugendhat, op. cit., s. 232 i n. oraz s. 257 i n.). 
przesyconą ideami śmierci - egzystencja wyczerpuje się w oczekiwaniu śmierci, nie można ryzykować doświadczenia, w którym człowiek wolny byłby od poczucia winy i daremności egzystencji. Idee oświecenia osadza Naruszewicz ostatecznie w paradygmacie dydaktyki religijnej ${ }^{52}$.

Posłuszeństwo regułom moralnym w dłuższej perspektywie ma sens, o ile służy ono namiętnościom — teizm staje się przykrywką dla uwodzicielskiej i uwodzącej miłości własnej Naruszewicza:

Tam się dopiero prawdziwie ucieszę,

Gdy równym torem do kresu przyśpieszę;

A same troski, podjęte dla cnoty,

Wieniec mi włożą w potomności złoty.

Powinniśmy być posłuszni regułom moralnym - służą one naszym namiętnościom: potrzebie zbawienia. Kategorie religijne są w istocie przykrywką dla miłości własnej, uwodzicielskiej pasji - pomimo pozorów połączenia cnoty z prawdą i pięknem, osiągniętą w ideale prezentowanym przez Naruszewicza. Sposób rozumienia rzeczywistości ludzkiej zabezpiecza Naruszewicza przed możnością zobaczenia zła, tam gdzie zdawało się rozciagać królestwo dobra.

W istocie w „Szczęśliwości” mamy do czynienia z częstym melanżem wątków kulturowych, które ukazują poetycką refleksję Naruszewicza o kulturze i moralności. Kosmologia poklasyczna pewności i ukorzenienia w kulturowo bezpiecznych i znanych obrazach już nie dawała. Filozofii nie udało się zagwarantować tego, co zapewniała religia: nagrody pośmiertnej. Tradycyjna kosmologia jawiła się jako niezbędny nosiciel treści religijnych, ukazujących uporządkowany wszechświat - kosmos poświadczający istnienie Boga ${ }^{53}$. Sfera, w której dąży się do szczęścia, przestała być sferą moralności - za sprawą usunięcia podmiotowości w panpsychicznych wyobrażeniach Naruszewicza. Tam zaś, gdzie odwołuje się do komunałów etyki stoickiej, oddzieli sferę szczęścia od wypełniania przykazań płynących z moralności Bożej. „Szczęśliwość” pokazuje recepcję idei oświecenia w twórczości Naruszewicza uzasadnienie dla nich jest najczęściej przejęte $\mathrm{z}$ tradycyjnych wątków kulturowych $^{54}$. Są one samouzasadniające się, jednak brak im już żywotności.

Całościowe rozumienie świata, łączące piękno i prawdę, etykę z fizyką i estetyką nie jawi się jako koherentne i spójne. Konstytutywny dla epoki model całościowy

52 Por. „Naruszewicz w większości swych filozoficzno-moralnych i politycznych utworów, zwłaszcza o charakterze perswazyjnym, swoje perswazje wyraża na ogół tak, by jego argumenty miały oparcie w ogólnie akceptowanym poglądzie" (B. Wolska, W świecie żywiołów op. cit., s. 194). Przywołanie treści dydaktyki religijnej zapewniałoby zgodność z opinio communis.

53 B. Wolska, op. cit., s. 59; N. Wildiers, op. cit., s. 26.

${ }^{54}$ Zwraca uwagę nieobecność wątków Maryjnych w twórczości Naruszewicza, powściągliwość w odwoływaniu się do postaci Chrystusa. Naruszewicz pomija także w swych tłumaczeniach także utwory Sarbiewskiego związane z Matką Boską (B. Wolska, op. cit., s. 203). 
oddaje jedynie specyfikę myśli czasów Naruszewicza czy Uza. Odpowiedź, jakiej Naruszewicz udziela, jest ze swego ducha chrześcijańska: doczesność nie przynosi szczęścia, obecny w niej problem cierpienia daje się zrelatywizować jedynie wraz z tym światem. Myśl oczywiście jest wypowiedziana w kategoriach całościowego ładu - ale odpowiedź nawiązuje do wyobrażeń eschatologicznych chrześcijaństwa. Tylko życie wieczne, a nie jakiekolwiek formy łączności z całością bytu wewnątrz tego świata mogą przynieść doświadczenie szczęścia. Consolatio dokonane zostaje zatem za sprawą wiary ${ }^{55}$.

\section{Re s ü m e e}

Im Aufsatz „,O Szczęśliwości` Adama Naruszewicza. Przyczynek do idei wielkiego łańcucha bytu" wird die idée fixe der Aufklärung aufgenommen: das Streben nach Vergnügen in der Lehrode „Szczéśliwośćc“ („Die Glückseligkeit“) von Adam Naruszewicz, die eine Paraphrase von „Die Glückseligkeit“" von Johann Peter Uz ist. Der Autor verbindet die aufklärerische Neuereraktivität mit voraufklärerischen Literatur- sowie Kulturtraditionen. Die Eigenart der neuzeitlichen Welterfahrung, die in Kategorien der Ganzheit stattfindet, war eine für das moderne Bewusstsein inakzeptable Verbindung von Esoterik und Theologie mit materialistischer Naturwissenschaft. Die naturphilosophische Erfahrung ging hingegen mit einem existentiellen sowie ästhetischen Erlebnis einher, wodurch sie zu einem Vortrag über die Moral mutierte. Naruszewicz verbindet ontologische Erwägungen über das Universum der Natur mit Bemerkungen aus dem Bereich der Ethik, was auch den kulturellen Rang der Zersetzung des aristotelischen Diskurses in der Aufklärung mit ihrem Bedürfnis nach einer rationellen Begründung der Moral (A. MacIntyre, E. Tugendhat) offenbart. Die Säkularisierung der Moral, die sich im 18. Jahrhundert herausgebildet hatte, hat den Status der Moral von göttlichen Geboten unterschieden. Als eine Konsequenz folgt daraus, dass die Moral rationeller Grundlagen sowie einer rationellen Begründung bedarf.

Witold Wojtowicz

Instytut Polonistyki

Uniwersytet Szczeciński

al. Piastów 40 B, PL-71 065 Szczecin

wojtowic@poczta.onet.pl

${ }^{55}$ O. Marquard, op. cit., s. 8; idem: Rozum jako reakcja graniczna. W sprawie przemiany rozumu za sprawą teodycei, w: idem: Szczęście w nieszczęściu, op. cit., s. 40-41. 